SBR

SMALL BUSINESS INTERNATIONAL REVIEW
JOURNAL: Small Business International Review

ISSN: 2531-0046

SECTION: Research Articles

VOLUME: 3; ISSUE: 2; PAGES: 1-16

DOI: https://doi.org/10.26784/sbir.v3i2.196

SUBMITTED: 2018-12-23

ACCEPTED: 2019-02-14

PUBLISHED: 2019-07-01

\title{
Resilient Organizational Capabilities in NTBFs. Concept and Variables as Dynamic and Adaptive Capabilities
}

\section{Capacidades organizativas resilientes en NEBTs. Concepto y variables como capacidades dinámicas adaptativas}

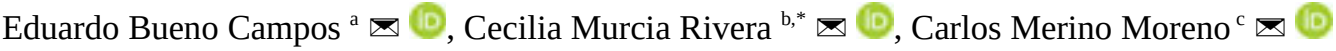 \\ a) Universidad a Distancia de Madrid (UDIMA), Spain \\ $b, c)$ Universidad Autónoma de Madrid (UAM), Spain \\ *Corresponding author: cecilia.murcia@inv.uam.es (Cecilia Murcia Rivera)
}

\begin{abstract}
In this paper we propose the concepts and variables that characterize resilient organizational capabilities (onwards ROC that can be viewed as dynamic capabilities. The concept of resilience highlights the ability to overcome trauma and the power to emerge more reinforced, considering the concept of "lessons learned" as the basis for its development. There are two key factors: attitudes and culture that can be transformed into a concept of resilience. In this work, the concept and characteristics of the ROC or "adaptive capabilities" generating innovation in the field of SMEs are presented. Also, the role of dynamic capabilities and intellectual capital that has been playing to date will be explained. In this research a methodological triangulation and a qualitative analysis to data on a Case Studies in new technology based firms (NTBFs) of the Scientific Park of Madrid and Colombian SMEs are realized. And will be completed with a quantitative analysis through the survey of these same two groups. The results of the comparative study show differences in analysed ROC, explained by cultural or economic themes, or by the sectors or sizes to which the companies of the reference groups belong, which is the basis for a future line of research.
\end{abstract}

Keywords: adaptive capabilities; dynamic capabilities; intellectual capital; organizational resilience; NTBFs; resilient organizational capabilities; ROC; SMEs JEL Classification: M13; M21; O31; O33

\section{Resumen}

En este trabajo, proponemos los conceptos y las variables que caracterizan las capacidades organizativas resilientes (en adelante, ROC) que pueden verse como capacidades dinámicas. El concepto de resiliencia destaca la capacidad de superar un trauma y el poder de emerger más reforzado, considerando el concepto de "lecciones aprendidas "como base para su desarrollo. Hay dos factores clave: las actitudes y la cultura que pueden transformarse en un concepto de resiliencia. En este trabajo, se presentan el concepto y las características de la ROC o “capacidades de adaptación” que generan innovación en el campo de las PYMES. Además, se explicará el papel que las capacidades dinámicas y el capital intelectual han estado jugando hasta la fecha. En esta investigación, se realiza una triangulación metodológica y un análisis cualitativo de los datos de estudio de casos en nuevas empresas de base tecnológica (NEBTs) del Parque Científico de Madrid y un grupo de Pymes Colombianas. Este se completará con un análisis cuantitativo a través de una encuesta realizada a estas mismas empresas. Los resultados del estudio comparativo, muestran diferencias en las ROC analizadas, explicados por temas culturales o económicos, o por los sectores o tamaños a los que pertenecen las empresas de los grupos de referencia, que serán la base de una línea de investigación futura.

Palabras clave: capacidades adaptativas; capacidades dinámicas; capital intelectual; resiliencia organizativa; NEBTs; capacidades organizativas de resiliencia; ROC; PYMEs

Clasificación JEL: M13; M21; O31; O33 


\section{Introduction}

In the last decades of the last century and first of the present the global economy and its markets has been leading a period of growing instability, uncertainty and turbulence, affecting the sustainability of the company in general and especially the survival, consolidation or development sustainable development of SMEs and, above all, of the NTBFs. Which has led to the incorporation of the concept of resilience, which is characteristic of Psychology and Psychiatric related to individual behavior from traumatic situations, disaster readiness, and reduction risk, in the field of Management, especially Strategic Management, as a novel approach to analyse the organizational behaviour in its orientation to the necessary entrepreneurial dynamics demanded by the current turbulent times, based especially on the theory of dynamic capabilities (Bueno, Longo-Somoza, Salmador, 2016).

Therefore, in this work an analysis is carried out on the basic approaches of the concept of resilience and its concretion in the Organisational Resilience (OR). In this sense, has been considered the contributions of Bhamra et al. (2011); Pavlou and El Sawy (2011), Kurtz and Varvakis (2016), among others, who have reviewed the conceptual content of resilience, especially in the organizational context and the possible configuration of Resilient Organisational Capabilities (ROC) in the framework of dynamic capabilities theory, from Teece (1998, 2009, 2014), Teece and Pisano (1994), Teece, Pisano and Schuen (1997), Eisenhardt and Martin (2000) and Wang and Ahmed (2007), among others, an evolutionary approach to the situation of the environment from the theoretical framework of resource-based theory (Wernerfelt, 1984 and 1995, Grant, 1991, Barney, 1991).

Evolutionary process will materialize in the generation of the dynamic and adaptive capabilities. In this context, it is possible to create dynamic SMEs in this environment (North and Varvakis, 2016a, 2016b). This approach will have empirical evidence through the analysis carried out in two different socioeconomic spaces, but with the same methodology and reference model, Bueno, \& CIC-IADE (2012) and Bueno, Merino and Murcia (2016), in a similar period of time in a Case Studies about 20 SMEs and NTBFs.

In sum, in the following section, the indicated conceptual analysis of resilience is carried out and, as well as the corresponding concept of ROC. In section 3, the necessary study is undertaken in the theoretical framework defined in the object of this paper of the ROC in its consideration of dynamic capabilities which will end in the characterization of the ROC in its key aspects in the NTBFs is made concrete. In section 4 the analysis is collected from Empirical study carried out in 6 NTBFs of the Science Park of Madrid (Spain) and in 14 innovative SMEs of Region of Antioquia (Colombia).

These results of this work, given its emerging character and exploratory nature, have allowed constructing conclusions consolidated in section 5. All of which concludes with references cited in the paper.

\section{Theoretical Framework: Conceptual analysis of resilience and organizational resilience}

The word resilience comes from the Latin word resilio, which means returning to a previous state. This concept has been applied in several disciplines, like physics and mathematics sciences where this term was originally used to describe the capacity of a material or system to return to equilibrium after a displacement (Norris et al, 2008).

According with these authors, the concept of resilience has been used to describe the adaptive capacities of individuals, human communities and larger societies.

In this sense, in 2013 , at the $29^{\text {th }}$ Plenary of meeting of the International Society for Traumatic Stress Studies, a group of multidisciplinary experts agreed that resilience is a complex construct 
and it may be defined differently in each context: individuals, families, organizations, societies, and cultures (Southwick et al, 2014). They also agreed that the empirical study of this construct needs to be approached from a multiple level of analysis perspective that includes genetic, epigenetic, developmental, demographic, cultural, economic, and social variables.

Likewise the American Psychological Association (2011) defines resilience as "the process of adapting well in the face of adversity, trauma, tragedy, threats or even significant sources of stress"

At the organizational level, the resilience concept has been defined as a superior capacity for reinventing the business model before circumstances force it (Hamel and Välikangas, 2003).

Although the context of the term may change, across all of these fields the concept of resilience is closely related with the capability and ability of an element to return to a stable state after a disruption Bhamra et al. (2011). This diversity of approach or multidisciplinary concept is shown in Table 1.

Resilience permeates a complete paradigm shift into various sectors of the company; in the "century of knowledge" companies need to respond quickly -based on Flexibility, Focus, Organization, Positive and Proactive- to external changes in a chaotic and unpredictable environment (Kurtz and Varvakis, 2016). In summary, as defined mainly by Hamel (2007), for an organization be a resilient system, it must first to accept reality; therefore, the organizational resilience (OR) as a response to firms, to face the instability of the markets, creating the necessary resilience organizational capabilities $(\mathrm{ROC})$ in order to recover the stability and balance. In sum, is the ability of a company to overcome the disturbance caused by external turbulences and still remain unchanged and competitive. In accordance with McDonald (2017) the OR conveys the properties of being able to adapt to the requirements of the environment and being able to manage the environments variability. Finally, this concept in agreement with Whitehorn (2011), included some behaviors such as agility, integration, leadership, change and communications.

Table 1. Concepts of Resilience: Main Approaches

\begin{tabular}{l|l}
\hline Context & \multicolumn{1}{c}{ Definition } \\
\hline Physical systems & $\begin{array}{l}\text { The flexibility and speed that a system has after a displacement and irrespective of } \\
\text { oscillations on it. (Bodin y Wiman, 2004) }\end{array}$ \\
\hline Psychology & $\begin{array}{l}\text { The developable capacity to rebound from adversity or the capacity of human } \\
\text { beings to adapt positively to adverse situations (Luthans et al, 2006) }\end{array}$ \\
\hline Individual & $\begin{array}{l}\text { Posses three common characteristics: an acceptance of reality, a strong belief that } \\
\text { life is meaningful and the ability to improvise (Coutu, 2002). }\end{array}$ \\
\hline Ecological Systems & $\begin{array}{l}\text { The capacity of a system to absorb disturbance and reorganise while undergoing } \\
\text { change while retaining the same function, structure, identity and feedback } \\
\text { (Walker et al., 2004) Another definition in this context is that resilience is the speed } \\
\text { at which a system returns to a single equilibrium point after a disruption (Tilman } \\
\text { and Downing, 1994). }\end{array}$ \\
\hline Socio-ecological systems & $\begin{array}{l}\text { The ability to maintain the functionality of a system when is perturbed or the } \\
\text { ability to maintain the elements required renewing or reorganising if a disturbance } \\
\text { alters the structure of funtion of a system. (Walker et. al, 2002). }\end{array}$ \\
\hline Engineering & $\begin{array}{l}\text { The ability to sense, recognize, adapt and understand changes, disturbances, } \\
\text { disruptions and surprises (Hollnagel et. al, 2006). }\end{array}$ \\
\hline Organizational & $\begin{array}{l}\text { The ability of a system to overcome the disturbance caused by external } \\
\text { phenomena, and still reamin unchanged. To survive in a turbulent world only } \\
\text { resilient companies will be able to see the changes causes in a crisis scenario } \\
\text { (Hamel, 2007). Resilience is present in successful organizations that understand the } \\
\text { dynamic nature of their business environments (Hamel \& Valikangas, 2003) }\end{array}$ \\
\hline
\end{tabular}

Source: Own elaboration based on Bhamra et al. (2011). 
This ROC, according to the "Resource-Based Theory" (Wernerfelt, 1984 y 1985; Grant, 1991 and Barney, 1991, among others), can be defined as "organizational routines, knowledge, attitudes or managerial skills that value both tangible and intangible resources, in the development of the organization's activities, as a potential for rapid response and adaptation to the turbulence of the environment".

Therefore, as will be analyzed in the following section, ROC represent a basic conceptual perspective in the definition of Business Dynamics (Bueno, Longo-Somoza, Salmador, 2016), as a new disciplinary approach, to develop an innovative, knowledge-based enterprise, and incorporating the concepts of dynamic and adaptive capabilities, based on the conceptual proposal of adaptive advantage (Bueno, 2016) as strategic directives, in the current socioeconomic environment (Bueno \& Morcillo, 2016).

Once the OR is defined and justified the need to develop ROCs, it is necessary to analyze and implement the processes that define them, (North and Varvakis, 2016a and 2016b), in order to respond to the necessary business dynamics, which will be based on an analysis of the causes and forces of the market that is promoting the instability and turbulence of the current economy (Bueno, Longo-Somoza and Salmador, 2016).

This approach reveals the strategic role in the ROC of knowledge and innovation as generators of critical intangible assets (Kurtz and Varvakis, 2016). Organizational behavior that will be based on an evolutionary approach, (Nelson and Winter, 1982), which will take shape in certain dynamic, adaptive, to define the adaptive advantage that company needs (Bueno and Morcillo, 2016).

For all this, the following point 3.1. shows first, a proposal for the characterization of ROC both as dynamic and adaptive capabilities that are manifested as the critical issue from the generation of an innovative culture in the company, based on the permanent creation of adaptive advantages and decisive role of innovation (Bueno and Morcillo, 2017).

All of which will be empirically validated applying a methodology based on case studies and methodological triangulation, as stated in point 4.

Finally, in section 3.2 is presented an analysis of the key aspects that explain the ROC, applied to the NTBFs.

\section{Resilient organizational capabilities as dynamic and adaptive capabilities}

As has already been indicated and as a consequence of the theoretical analysis carried out in point 2, below is shown, firstly, a proposal to characterize ROC as a dynamic and also adaptive capability, which allow defining them as an adaptive advantage and, secondly, a proposal of the key aspects that define ROC in their application in the innovation processes of SMEs, especially in NTBFs.

\subsection{Characterization of resilience organizational capabilities as dynamic and adaptive capabilities; the adaptive advantages}

According to Wang and Ahmed (2007) once the processes or activities of the dynamic capabilities are characterized, 3 components can be identified: a) Adaptation, (b) absorption and (c) innovation. First component is responsible for strategically linking resources and capabilities with competitive external market factors. Second, focus on the processes of organizational learning as the development of the necessary competitive intelligence for the achievement of adaptive advantage and the third one explain the necessary relationship that the resources and capabilities possessed by organization respond to the needs of the market by creating the goods, services, business, management, etc. to be able to compete and achieve sustainable development (Bueno and Morcillo, 2017).

Finally, in order to make dynamic capabilities allow the characterization of ROCs, it is important to focus on the concept of adaptive capabilities, that is, as dynamic capability, but 
based on an innovative corporate culture and a perspective of "innovative entrepreneurship" To put the emphasis on the imperative of change, to create the required business dynamics (Bueno, 2015). Especially SMEs and among them NTBFs, can adapt to it and compete to ensure their survival or sustainable development.

In summary, Adaptive advantage can be defined as follows:

"It is generated by the chosen corporate innovative culture model and that allows the company to appropriate, transmit and share the utility of the innovations, before and better than the competitors. That is, a concept that represents a more dynamic way to respond "on time" to the pretended business dynamics" (Bueno, Longo-Somoza y Salmador, 2016, p. 16).

A proposal that according to Teece and Pisano (1994) and Teece, Pisano and Shuen (1997) represent "the company's ability to continuously modify its resources base and capabilities so that it always adapts to fast-changing environments". Insisting on this proposal, for Eisenhardt and Martin (2000) such capabilities are "the processes, activities and business functions that use the resources specifically to integrate, redesign, increase and release them in order to be able to compete and create the level of performance they demand the changes of the market". (p.1107).

On the other hand, according to Winter (2003), dynamic capabilities are "those that allow enriching, modifying or creating ordinary or basic capacities that guarantee short-term survival" (p. 991), in relation to the corresponding corporate strategy. Finally, Teece (2012) indicates that the aforementioned capabilities must be understood as "'strategic' and distinct from ordinary capabilities. Firms can maintain and extend competitive advantage by layering dynamic capabilities on top of ordinary capabilities." (p.1396).

Following Teece (2007) characterization of the dynamic capabilities is defined by three processes: sensing; seizing, and reconfiguring. These make it easier for the organization to identify, absorb, create, distribute and protect knowledge-based intangible assets that support current performance, generate competitive advantages and ensure sustainable development.

According to Pavlou and El Sawy (2011), dynamic abilities based on knowledge as a resource to compete in turbulent environments, as well as to develop in the same way in North and Varvakis (2016b), its processes and explanatory activities are: to detect, to learn, to integrate and to coordinate. In such way these capabilities can be used to characterize ROCs in their dynamic capability nature:

- Detection capability: Technological surveillance processes of the resources and capabilities that are considered critical and necessary to be able to compete and achieve a sustainable development in turbulent environments.

- Learning ability: Processes to absorb external knowledge and to create the internal necessary in the specific activities of the individual, group and organizational learning, that provides the knowledge as resource and strategic capability to be able to compete. Capability for integration. Processes to achieve an adequate integration of the different knowledge (explicit - tacit, individual - collective and internal - external) from the corresponding model of knowledge governance

- Coordination capability: Processes that from the necessary innovative culture and of the indicated model of knowledge governance can facilitate that the previous capabilities can be concretized in a certain strategy that facilitates the adaptation of the company and its sustainable development to the current economic change situation and from an evolutionary approach, as discussed below.

In order to explore how the assessment and management of knowledge assets can support process performance improvements, we have carried out an empirical research based on multiple case studies (Eisenhardt, 1989; Yin, 1984). 


\subsection{Key aspects in the resilience organizational capabilities of NTBFs}

The ability to overcome adversity under highly changing and even turbulent environments (North and Varvakis, 2016a) highlights the need to work a number of factors internally within organizations. In the case of SMEs, and especially in the case of NTBFs, resilience is a key aspect to overcome the so-called "death valley" that is reflected in all studies of the Global Entrepreneurship Monitor Project GEM (2015).

Obviously, the essence of NTBFs is that their real business is R \& D \& I itself, so resilience must be treated as organizational capability, as system, which allows the development of innovation both proactively and reactively in order to generate "adaptive advantages" (Bueno and Morcillo, 2016).

In this way, resilience is the reaction in which the company solves the changes and turbulences, more or less predictable and even unforeseeable issues (North y Varvakis, 2016b).

In order to establish a framework for its analysis, it is useful the intellectual capital approach (Bontis, 2001) in which the intangible assets of organization are concentrated in 3 large dimensions, namely people, structures and relationships. Therefore, there are attitudes, knowledge, organizational elements and networks on the basis for creating the resilience potential. In this sense, from the analysis of highlighted elements for North and Varvakis (2016b) and variables from Intellectus Model (Bueno, CIC-IADE, 2003) related with Intellectual Capital of NTBFs, considered as a guideline for the development of R \& D and creation of innovation in these firms (Bueno, Merino y Murcia, 2016), the following key factors have been considered for the analysis of the resilient organizational capabilities of NTBFs. Proposal of key factors that summarize, in particular. the aspects and characters that have been analyzed in point 3 above on the concept of OR and that will allow to carry out their contrast or validation with the empirical analysis of the resilience organizational capabilities of NTBFs (non-resilient) that will be carried out in the point 4 below with the subsequent case studies.

- Agile and solvent management leadership. Reaction requires quick and clear management leadership as well as convincing to the members of the organization.

- Attitude of commitment of the whole organization. Resilience from a corporate perspective demonstrates a systemic approach, which is a powerful condition of sense of belonging that allows even the development of extra efforts.

- Effective teamwork. As part of the philosophy of any innovative organization, collaboration is key and resilience is addressed from effective collaborative dynamic.

- Staff talent. Skills, attitudes, experiences, etc., build the basis of talent and in this factor lies much of the creation of solutions that requires resilience. Attitude that is based on the existence of an innovative culture in the organization, foundation to create adaptive advantage that results in a ROC (Bueno and Morcillo, 2017).

- Creative and innovative staff spirit. As an essential part of a innovative company, the very creative and innovative condition that characterizes it is important to even turn resilience into a base that enhances the questioning attitude and therefore the development of innovations.

- Agility and process adjustment. From a more structural part to having internal work patterns that are fast and fit to become allies of timing that requires resilience.

- Business flexibility. Aspects such as the possibility of varying organizational design in an agile way, making or getting rid of resources and being able to adjust costs are also key elements in this area of resilience.

- External networking support. Since the part of relationships have external support derived from different agents (clients, suppliers, laboratories, institutions, etc.) can be vital for resilience. 
These eight factors have been taken into account to develop a questionnaire (see Annex 1), and has been used to analyze the resilience of 6 NBTFs housed in the Madrid Science Park (PCM) and 14 innovative SMEs from the region of Antioquia in Colombia. Analysis that has followed the methodology of Case Study (Yin, 2017) with the purpose of the confirmation to start from a methodological triangulation and whose results are presented in the following section.

\section{Methodology: Empirical analysis of resilience organizational capabilities in NTBFs and innovative SMEs}

Consequently, to confirm ROCs as dynamic capabilities in the NTBFs, an empirical analysis has been carried out on 20 companies of this nature in two different economic fields and in the same time period. In the Madrid Science Park (Spain), in particular 6, and the remaining 14 in the Region of Antioquia (Colombia). Research that has been based on a methodological triangulation (Arias, 2000; Rodríguez, 2005) relating the theoretical framework considered with quantitative and qualitative methods when elaborating both questionnaires and indepth interviews, which ended in the corresponding Case Studies. The results obtained are shown, respectively, in the following headings 4.1 and 4.2 .

\subsection{Case studies in NTBFs of the Madrid Science Park (PCM). Results}

The Madrid Science Park (PCM) is a support structure for the enterprise that has been hosting NBTFs for more than 15 years. The orbit of organizations linked to the Park reaches 120 , which is an essential center for understanding the phenomenon of these companies in Spain.

The 8 factors previously described to measure the ROC have been studied in 6 NBTFs as confirmation cases of the importance of them, as recorded in the technical file of Table 2. In each case, there have been asked for phrases representative of their assessments in order to be able to show opinions that can help to understand details of the ROC.

The results for each of the 8 factors have been collected on a likert scale of 1 to 5 and are then sorted by their mean values (Table 3).

\begin{tabular}{|c|c|c|}
\hline \multicolumn{3}{|c|}{ Table 2. Case studies in the PCM } \\
\hline \multicolumn{3}{|c|}{ Technical Data } \\
\hline $\mathrm{N}^{\circ}$ NTBFs & \multicolumn{2}{|l|}{6} \\
\hline \multirow[t]{2}{*}{ Analysis Period } & \multicolumn{2}{|l|}{ January-March 2017} \\
\hline & \multicolumn{2}{|l|}{ Madrid Science Park } \\
\hline Sectors of activity & \multicolumn{2}{|c|}{2 health, 1 finance, 2 engineering, 1 consulting } \\
\hline \multicolumn{3}{|c|}{ Source: Own elaboration } \\
\hline \multicolumn{3}{|c|}{ Tabla 3. Assessment of key aspects for resilience in NTBFs } \\
\hline & tors & Average Rating \\
\hline Attitude of comn & of the whole organization & 5,00 \\
\hline Agile and solven & ement leadership & 4,66 \\
\hline Effective teamwc & & 4,50 \\
\hline Staff Talent & & 4,16 \\
\hline Creative and inn & taff spirit & 3,83 \\
\hline External networ & port & 3,66 \\
\hline Business flexibili & & 3,50 \\
\hline Agility and proce & tment & 3,00 \\
\hline
\end{tabular}

Source: Own elaboration 
As can be appreciated in a general way, there is an important conclusion, and it is that the NTBFs place the most structural solutions that are typical of most SMEs, that is, reduce expenses, reconfigure the organization, which seeks quick solutions in the income statement. This shows a work culture more linked to adaptation than to survival.

In the context of the attitude those responsible for these organizations have made comments such as the following, "the best thing this company has is people's commitment", or "resilience is a key issue of attitude, adversity is not a problem but a condition".

From the leadership level some comments were as follows: "decisions can not wait, they must be very clear and reach all people. If you have to stop, stop "', it is necessary that what is decided is consistent so that you trust what is proposed".

For the factor of teamwork the comments focused on: "resilience is a team issue, it does not depend on the happy idea of a person," "the key to resilience is in the conjunction of points of view. You always get a more complete solution".

In the case of staff talent, the following statements were highlighted: "we must take advantage of change as a condition and feel resilience as an element that supports the differentiating effect of our talent", "the talent of our human group stands out in key moments".

In consequence these 4 factors are those that have obtained an average qualification greater than 4 agglutinating the greater explanation of the ROC for the companies analyzed. Obviously the results require a study in greater depth and size of the same to be considered in general, nevertheless, they show a marked character of core competences in the NTBFs that identify the ROC as dynamic capabilities (Kurtz and Varvakis, 2016).

Following the comments on the other factors, in the case of the creative and innovative spirit was mentioned: "sometimes resilience does not always require the consideration of innovative responses, leads to important decisions for market positioning rather than component Innovative", "creativity and innovation are important in creating resilience".

Therefore, the average value is quite high but half the companies have put a rating of 3 .

On the side of the external networking support, the comments moved from a high valuation, for example, "it is necessary to have good external collaborators to solve adverse situations, sometimes they are the key", and others of lower level: "resilience can have external support but it depends on us".

It is a factor that can depend a lot on the reality of business or sector. The results have been high in finance and health.

In the case of business flexibility, in SMEs has been notorious for their preference for this type of decisions, however in NTBFs has importance but not priority. Thus have been obtained comments as: "reconsider aspects of resources and costs has helped us," "have not been the issues we have begun to reflect".

Finally, for the agility and adjustment of the processes all the companies have been awarded the value of 3 , an average value that represents relative importance in the ROC. The comments have been very significant: "what we do has a very specific methodology, it is not a matter of changing the way of doing" "adjustments have been made in processes but always considered as minor adjustments."

Once commented one by one the eight factors can be argued the understanding of the ROC in the NTFBs of the Madrid Science Park from 2 dimensions. The first one based on commitment, leadership and collaboration, and the second characterized by skills, adjustments and networks. In the study carried out in Colombia it will be possible to appreciate that the results confirm a large part of this argument, that is, with some particular difference. 


\subsection{Case studies in SMEs in the Antioquia region (Colombia). Results}

The main purpose of this research was to identify the determinants of resilience in a group of SMEs considered innovative in Colombia, specifically in the Region of Antioquia. This region concentrates $15 \%$ of the total of the companies in the country, of which SMEs represent $85 \%$. Likewise, in this region there is a high business mortality represented by an average disappearance of $29 \%$ of SMEs in the third year of operation (Ospina, O.M., 2011).

In this way, it is a priority to know the factors that can contribute to their survival. For this reason, the 8 factors to measure the ROC, mentioned in point 3.2, have been evaluated in 14 innovative SMEs in order to validate their importance, as shown in the data sheet of Table 4 In this sense, SMEs participating in the research, to be considered innovative, had to comply with the characteristics of more than 5 years old and the development of $R \& D$ activities, or their interest in developing them.

Based on the results obtained from the questionnaire applied (see annex 1), and from the interviews carried out with the executives of the participating SMEs, the analysis of them is carried out below (Table 5).

As we can see in the previous graph, the factors selected to try to explain certain key components of resilience show a lot of relevance given that except for the last one (staff talent) the rest is above 4 average rating.

What is significant are the factors that lead the valuations representing an important relationship between resilience and attitudinal and solidarity elements. Actually, the sense of collective identity is identified as a significant basis for this capacity that is based on group work, collaboratively, in the context of solid relationships.

These three factors show that resilience is not fundamentally a matter of knowing how to manage adversity, but of wanting from a collective approach where all internal and external supports count. Therefore, the climate of relationships and the collaborative culture (internal and external) are positioned as key issues to endow an organization with that resilience.

\begin{tabular}{|c|c|c|}
\hline \multicolumn{3}{|c|}{ Table 4. Case studies in the Antioquia Region (Colombia) } \\
\hline \multicolumn{3}{|c|}{ Technical Data } \\
\hline $\mathrm{N}^{\circ}$ Innovative SMEs & 14 & \\
\hline Analysis period & January to March 2017 & \\
\hline Place & SMEs affiliated to the $F$ & imily Compensatio \\
\hline & Fund of Antioquia - Co & nfama (Medellín-C \\
\hline \multirow[t]{2}{*}{ Sectors of activity } & 4 manufacturing; 1 cor & struction; 3 Comme \\
\hline & $\begin{array}{l}1 \text { Hotels, restaurants, } \mathrm{b} \\
\text { communal and person }\end{array}$ & $\begin{array}{l}\text { rs; 1 Social Services } \\
\text { l; } 4 \text { Services to com }\end{array}$ \\
\hline \multicolumn{3}{|c|}{ Source: Own ellaboration. } \\
\hline \multicolumn{3}{|c|}{ Table 5. Assessment of key aspects for resilience in SMEs } \\
\hline \multicolumn{2}{|c|}{ Factors } & Average Rating \\
\hline \multicolumn{2}{|c|}{ Attitude of commitment of the whole organization } & 4,93 \\
\hline \multicolumn{2}{|c|}{ Effective teamwork } & 4,79 \\
\hline \multicolumn{2}{|c|}{ External networking support } & 4,64 \\
\hline \multicolumn{2}{|c|}{ Agile and solvent management leadership } & 4,50 \\
\hline \multicolumn{2}{|c|}{ Creative and innovative staff spirit } & 4,29 \\
\hline \multicolumn{2}{|c|}{ Agility and process adjustment } & 4,21 \\
\hline \multicolumn{2}{|c|}{ Business flexibility } & 4,21 \\
\hline \multicolumn{2}{|l|}{ Staff Talent } & 3,79 \\
\hline \multicolumn{3}{|c|}{ Source: Own el } \\
\hline
\end{tabular}


Going into some specific issues of these factors, first of all the "attitude of commitment of the entire organization", the importance of "relationships between managers and employees based on trust, participation, labor flexibility, solidarity ... "to create an environment conducive to the capacity associated with resilience. Secondly, the factor "effective teamwork" is highly valued, especially by some companies, such as the Confecciones where "the sense of the production chain emphasizes the need for this collaborative work that is exemplified in product meetings, where feedback is given to the entire organization on the role that each plays in achieving common objectives (...) as well as the continuous improvement programs in which some of the companies are immersed ".

Finally, the "external networking support" factor expands the collaborative context to external stakeholders, especially with customers. In most of the companies in the study, "there is joint work with customers in relation to the design of products and services".

After that core of factors that leads the valuations, there appear other 4 factors that establish a second layer of articulation of the resilience and that are determined by the operability of the same, that is to say, to have profiles that on the one hand reinforce the 3 previous factors besides to lead the decision process that can make that resilience effective, either from the promotion of creative talent or from the reconfiguration of processes or business schemes. In short, executive leadership is required to guide and secure internal movements that are the effective sign of resilience.

Considering some specific opinion derived from the interviews, the factor "agile and solvent management leadership", there is a consensus that "it is not the manager or Director the unique leader of the organization; depending on the structure, the majority of companies choose -in a voluntary way among employees- leaders by activity areas or primary groups, diluting in this way, the only responsibility that the Manager or Director would have, who assumes the functions of facilitator".

Finally, the staff talent appears which, as mentioned above, is important given that this talent can play a very important role in the creative and innovative staff spirit, nevertheless, the resilience (seen in the evaluations) seems to be closer in essence to the attitudes than aptitudes.

Regarding this last factor "Staff talent" the interviews show the high value that is given to "attitudes and other characteristics personal issues related to commitment and teamwork, which will better guarantee good performance in these organizations".

For all the above, two general considerations can be made:

1. The existence of factors highly valued in line with the availability of a favorable context that resilience is a characteristic of the organization.

2. The tangibilization of resilience in terms of leadership and adjustments, that is, resilience in action.

\section{Conclusions}

Once the concept of resilience, its multidisciplinary study and cognitive evolution has been analyzed, itsconceptualization as OR has been carried out, as well as thenecessary development and concretion of the ROC as the directional attitudes or abilities, from the Resource -based Theory and the current approach to dynamic capabilities, as has been gathered in section 2 .

With these foundations in section 3 , the ROC has been characterized in terms of dynamic capabilities, according to the relevant literature of the theoretical frame of reference.

This characterization of the ROC has been corroborated with the empirical analysis carried out, which has been included in section 4. A parallel study of 20 SMEs that respond to the typology of NTBFs and innovative character in two different spaces, but following the same 
methodology and in the perspective developed in the paper to identify dynamic capabilities as variables of intellectual capital acting as accelerators of entrepreneurship and innovation value according to the Intellectus Model referenced.

For this reason, Table 6 shows the aforementioned characteristic variables of ROC, both as dynamic capability or as "accelerator" and in each of the basic processes or activities in which they are constructed; So that the relationships that validate cognitive communality are offered of the three concepts considered.

In this sense, the eight key factors for ROC analysis has been the next:

- Agile and solvent management leadership

- Attitude of commitment of the whole organization

- Effective teamwork

- Staff Talent

- Creative and innovative staff spirit

- Agility and process adjustment

- Business flexibility

- External networking support

Consequently, the previous section contains the results obtained in the Case Study of the 6 NTBFs located in the Science Park of Madrid (Spain) and the 14 innovatives SMEs of the region de Antioquia (Colombia). Results that demonstrate the strategic importance of the ROC so that this type of companies can survive and consolidate to be able to compete and achieve sustainable development.

Finally, and according to the results obtained in this kind of companies, Table 7 ntegrates the results obtained in two areas of case studies carried out, as set out in point 3.2.

Comparatively and although the valuation results in both groups of companies are similar, we find some differences in factors, such as "agile and efficient managerial leadership" "external networking support" that can be explained by cultural or economic themes, or by the sectors or sizes to which the companies of the reference groups belong, which is the basis for a future line of research.

\begin{tabular}{|c|c|c|c|}
\hline Processes & Dynamic capabilities & Intellectus Model accelerators & ROC \\
\hline $\begin{array}{l}\text { Sensing } \\
\text { Capability }\end{array}$ & $\begin{array}{l}\text { Spot, interpret and pursue } \\
\text { opportunities }\end{array}$ & $\begin{array}{l}\text { T.EA. (Entrepreneurial } \\
\text { attitude rate) }\end{array}$ & $\begin{array}{l}\text { Capability of predict factors } \\
\text { that can affect business }\end{array}$ \\
\hline $\begin{array}{l}\text { Learning } \\
\text { capability }\end{array}$ & $\begin{array}{l}\text { Revamp existing operational } \\
\text { capabilities with new } \\
\text { knowledge }\end{array}$ & Innovative culture & $\begin{array}{l}\text { Capability for adapting to } \\
\text { changes naturally. }\end{array}$ \\
\hline $\begin{array}{l}\text { Integrating } \\
\text { Capability }\end{array}$ & $\begin{array}{l}\text { Embed new knowledge into } \\
\text { operational capabilities with } \\
\text { collective sense-making }\end{array}$ & $\begin{array}{l}\text { International, } \\
\text { Technological, } \\
\text { Process, tinnovation } \\
\text { Business model and } \\
\text { Social Innovation and } \\
\text { Also Corporate Social } \\
\text { Responsibility }\end{array}$ & $\begin{array}{l}\text { Capability of recognizing the } \\
\text { leaders using clear objectives } \\
\text { and goals toward their actions }\end{array}$ \\
\hline $\begin{array}{l}\text { Coordinating } \\
\text { Capability }\end{array}$ & $\begin{array}{l}\text { Deploy tasks, resources, and } \\
\text { activities in reconfigured } \\
\text { operational capabilities }\end{array}$ & Management innovation & $\begin{array}{l}\text { Capability to track the results } \\
\text { obtained }\end{array}$ \\
\hline
\end{tabular}

Source: Own elaboration based on Pavlou and El Sawy (2011). 


\begin{tabular}{l|l|l|l}
\hline \multicolumn{4}{c}{ Table 7. Assessment of factors that characterize ROCs } \\
\hline \multicolumn{1}{c}{ PCM Cases (España) } & \multicolumn{1}{c}{ Antioquia Region Cases (Colombia) } \\
\hline Attitude of commitment of the whole organization & 5.00 & Attitude of commitment of the wholeorganization & 4.93 \\
Agileand solvent management leadership & 4.66 & Effective teamwork & 4.79 \\
Effective teamwork & 4.50 & External networking support & 4.64 \\
Staff Talent & 4.16 & Agileand solvent management leadership & 4.50 \\
Creativeand innovative staff spirit & 3.83 & Creativeand innovative staff spirit & 4.29 \\
External networking support & 3.66 & Agility and process adjustment & 4.21 \\
Business flexibility & 3.50 & Businessflexibility & 4.21 \\
Agility and processadjustment & 3.00 & Staff Talent & 3.79 \\
\hline
\end{tabular}

Source: Own elaboration.

Finally, due to the complexity and emergent nature of the organizational resilience issue, and the exploratory nature of this research, the results obtained have limitations, to be considered in a general way, being necessary, as a future line of research, to carry out studies in greater depth and size, contemplating in turn, different scenarios, countries that allow a more complete analysis on this subject.

Taking into account the results of the 2 studies conducted in parallel, the ROCs are based mainly on commitment and collaboration where leadership takes an important role. Therefore, in an organization that does not have an opportune work environment of collective sacrifice and identity, a culture of teamwork, solidarity, or a leadership that adequately mobilizes both issues, resilience will be a utopia.

After these basic factors, the issues related to the creative potential and adjustment dynamics are positioned, that is, the part related to finding solutions, provided that the commitment, collaboration and leadership are insured. Finally, the fundamental difference between Madrid and Antioquia is determined by the assessment given to external networks, very different in both realities, which can be interpreted as the understanding of resilience in a context where innovative SMEs consider that in addition to having internal ROCs is fundamental to the system of interest groups (institutions, aid programs, investments, client support, etc.) that have to support these organizations and contribute to the ROCs. 
Annex 1. Questionnaire

BRIEF QUESTIONNAIRE ON RESILIENCE

Dear friend,

MARCH 2017

We are developing a brief study on the concept of resilience in new technology-based companies. The concept of resilience refers to the ability to adapt and overcome adversity. In this sense, we would like you give us your answer to this brief questionnaire. It will take only 3 minutes.

The ability to adapt and overcome adversity in your company resides fundamentally in: (1 no relevant -5 very relevant)

An agile and solvent management leadership

$1 \quad 2 \quad 3 \quad 4 \quad 5$

Write a phrase that describes this rating

\section{Attitude of commitment of the whole organization}

$\begin{array}{lllll}1 & 2 & 3 & 4 & 5\end{array}$

Write a phrase that describes this rating

Effective teamwork

$\begin{array}{lllll}1 & 2 & 3 & 4 & 5\end{array}$

Write a phrase that describes this rating

\section{Staff Talent}

$\begin{array}{lllll}1 & 2 & 3 & 4 & 5\end{array}$

Write a phrase that describes this rating

\section{Agility and process adjustment}

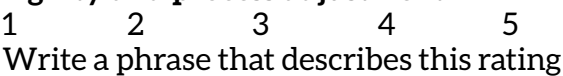

\section{Creative and innovative staff spirit}

$\begin{array}{lllll}1 & 2 & 3 & 4 & 5\end{array}$

Write a phrase that describes this rating

Business flexibility (organizational design, resources, expenses)

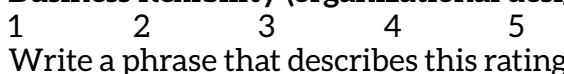

Write a phrase that describes this rating

External networking support

$1 \quad 2 \quad 3 \quad 4 \quad 5$

Write a phrase that describes this rating

¡Thank you very much for your cooperation!

If you wish, we will send you the publication with the results. 


\section{References}

American Psychological Association. (2011). The road to resilience. Washington, D.C., US: APA. Retrieved from APA.ORG

Arias-Valencia, M. M. (2000). La triangulación metodológica: sus principios, alcances y limitaciones. Investigación y Educación en Enfermería, XVIII(1), 13-26. Recovered https://dialnet.unirioja.es/servlet/ articulo?codigo $=5331864$

Barney, J. (1991). Firm Resources and Sustained Competitive Advantage. Journal of Management, 17(1), 99-120. https://doi.org/10.1177/014920639101700108

Bhamra, R., Dani, S., \& Burnard, K. (2011). Resilience: the concept, a literature review and future directions. International Journal of Production Research, 49(18), 5375-5393. https://doi.org/10.1080/00207543.2011 .563826

Bodin, P., \& Wiman, B. (2004). Resilience and other stability concepts in ecology: Notes on their origin, validity, and usefulness. ESS Bulletin, 2(2), 33-43. Recovered: https://www.researchgate.net/ publication/236208772_Resilience_and_Other_Stability_Concepts_in_Ecology_Notes_on_their_ Origin_Validity_and_Usefulness

Bontis, N. (2001). Assessing knowledge assets: a review of the models used to measure intellectual capital. International Journal of Management Reviews, 3(1), 41-60. https://doi.org/10.1111/1468-2370.00053

Bueno, E. (2003). Modelo Intellectus: Medición y Gestión del Capital Intelectual (Documentos Intellectus №5). Madrid, España: CIC-IADE. Universidad Autónoma de Madrid.

Bueno, E. (2012). Modelo Intellectus: Medición y gestión del capital intelectual, Madrid, CIC-IADE (UAM), Documento Intellectus n 9/10. Madrid, España: CIC-IADE. Universidad Autónoma de Madrid.

Bueno, E. (2015). Cómo dinamizar la pyme en el entorno económico actual. Análisis de los procesos y fuerzas de cambio. Revista de La AECA. Especial XVIII Congreso, Sept.-Oct., 111, 12-14. http://www. aeca1.org/revistaeca/revista111/111.pdf

Bueno, E. (2016). Dinámica empresarial y creación de ventajas adaptativas en el desarrollo sostenible. Revista de La AECA, Especial XVII Encuentro, Sept., 115, 3-5, Retrieved from http://www.aeca1.org/ revistaeca/revista115/115.pdf

Bueno, E., \& Morcillo Ortega, P. (2016). La innovación empresarial como generadora de ventajas adaptativas para la sostenibilidad. Comunicación Al XVII Encuentro AECA, Sept., Braganza( Portugal ), Proceedings. Retrieved from http://www.xviiencuentroaeca.ipb.pt/docs/artigos/24c.pdf

Bueno, E., \& Morcillo Ortega, P. (2017). Innovación. Dimensión Conceptual. Opinion Emerging Issue, nº 1. Retrieved from https://aeca.es/wp-content/uploads/2014/05/OE1os.pdf

Bueno, E., Merino, C., \& Murcia, C. (2016). Intellectual Capital as a Strategic Model to Create Innovation in New Technology Based Firms. In K. North \& G. Varvakis (Eds.), Competitive Strategies for Small and Medium Enterprises (pp. 93-105). Cham, Switzerland: Springer. https://doi.org/10.1007/978-3-319-27303-7_6

Bueno, E., Longo-Somoza, M., y Salmador, M. P. (2016). Concepto, método y programa de investigación de la dinámica empresarial. Economía Industrial, (399), 2-22. Recuperado de https://dialnet.unirioja.es/ servlet/articulo?codigo $=5542723$

Coutu, D. L. (2002). How resilience works. Harvard Business Review, 80(5), 46-55, May. Retrieved from https://hbr.org/2002/05/how-resilience-works

Eisenhardt, K. M., \& Martin, J. A. (2000). Dynamic capabilities: what are they? Strategic Management Journal, 21(10-11), 1105-1121. https://doi.org/10.1002/1097-0266(200010/11)21:10/11<1105::AIDSMJ133>3.0.CO;2-E 
Global Entrepreneurship Monitor. (2015).Informe GEM-España 2015. Banco Santander, España: Asociación RED GEM España. Recuperado de http://www.gem-spain.com/wp-content/uploads/2015/03/ Informe-GEM-2015-esafp.pdf

Grant, R. M. (1991). The Resource-Based Theory of Competitive Advantage: Implications for Strategy Formulation. California Management Review, 33(3), 114-135. https://doi.org/10.2307/41166664

Hamel, G. (2007). The future of Management. Boston (MA), US: Harvard Business School Press.

Hamel, G., \& Välikangas, L. (2003). The Quest for Resilience. Harvard Business Review, 81 (9), September, 52-63.Retrieved from https://hbr.org/2003/09/the-quest-for-resilience

Kurtz, D. J., \& Varvakis, G. (2016). Dynamic Capabilities and Organizational Resilience in Turbulent Environments. In, K. North, \& G. Varvakis (Eds.), Competitive Strategies for Small and Medium Enterprises (pp. 19-37). Cham, Switzerland: Springer. https://doi.org/10.1007/978-3-319-27303-7_2

Luthans, F., Vogelgesang, G. R., \& Lester, P. B. (2006). Developing the Psychological Capital of Resiliency. Human Resource Development Review, 5(1), 25-44. https://doi.org/10.1177/1534484305285335

McDonald, N. (2017). Organisational Resilience and Industrial Risk. In E.Hollnagel, D. Woods \& N. Leveson (Eds.), Resilience Engineering (pp. 155-180). London, UK: CRC Press. https://doi. org/10.1201/9781315605685-16

Nelson, R. R., \& Winter, S. G. (1982). An evolutionary theory of economic change. Cambridge (MA), US: Belknap Press of Harvard University Press.

Norris, F. H., Stevens, S. P., Pfefferbaum, B., Wyche, K. F., \& Pfefferbaum, R. L. (2008). Community Resilience as a Metaphor, Theory, Set of Capacities, and Strategy for Disaster Readiness. American Journal of Community Psychology, 41(1-2), 127-150. https://doi.org/10.1007/s10464-007-9156-6

North, K. \& Varvakis, G. (2016a). La Pyme dinámica. Estrategias para competir en tiempos turbulentos. Economía Industrial, 399, 65-74. Recovered https://dialnet.unirioja.es/servlet/articulo?codigo=5542784

North, K., \& Varvakis, G.(Eds.). (2016b).Competitive Strategies for Small and Medium Enterprises. Switzerland, Springer, Cham. https://doi.org/10.1007/978-3-319-27303-7

Ospina, O. M. (2011). Análisis de las principales características de las empresas en Antioquia. Revista Antioqueña de Economía y Desarrollo - RAED, 2, 6-25. Recuperado de https://docplayer.es/1568707Edicion-no-2-issn-2248-4329-revista-antioquena-de-economia-y-desarrollo.html

Pavlou, P. A., \& El-Sawy, O. A. (2011). Understanding the Elusive Black Box of Dynamic Capabilities. Decision Sciences, 42(1), 239-273. https://doi.org/10.1111/j.1540-5915.2010.00287.x

Rodríguez-Ruiz, Ó. (2005). La Triangulación como Estrategia de Investigación en las Ciencias Sociales. Revista Madri+d, 31. Recuperado http://www.madrimasd.org/revista/revista31/tribuna/tribuna2.asp

Southwick, S. M., Bonanno, G. A., Masten, A. S., Panter-Brick, C., \& Yehuda, R. (2014). Resilience definitions, theory, and challenges: interdisciplinary perspectives. European Journal of Psychotraumatology, 5(1), 25338. https://doi.org/10.3402/ejpt.v5.25338

Teece, D. (2009). Dynamic Capabilities \& Strategic Management Organizing for Innovation and Growth. New York, US: Oxford University Press.

Teece, D. J. (1998). Capturing Value from Knowledge Assets: The New Economy, Markets for Know-How, and Intangible Assets. California Management Review, 40(3), 55-79. https://doi.org/10.2307/41165943

Teece, D. J. (2007). Explicating dynamic capabilities: the nature and microfoundations of (sustainable) enterprise performance. Strategic Management Journal, 28(13), 1319-1350. https://doi.org/10.1002/ smj.640 
Teece, D. J. (2012). Dynamic Capabilities: Routines versus Entrepreneurial Action. Journal of Management Studies, 49(8), 1395-1401. https://doi.org/10.1111/j.1467-6486.2012.01080.x

Teece, D. J. (2014). The Foundations of Enterprise Performance: Dynamic and Ordinary Capabilities in an (Economic) Theory of Firms. Academy of Management Perspectives, 28(4), 328-352. https://doi. org/10.5465/amp.2013.0116

Teece, D. J., Pisano, G., \& Shuen, A. (1997). Dynamic capabilities and strategic management. Strategic Management Journal, 18(7), 509-533. https://doi.org/10.1002/(SICI)1097-0266(199708)18:7<509::AIDSMJ882>3.0.CO;2-Z

Teece, D., \& Pisano, G. (1994). The Dynamic Capabilities of Firms: an Introduction. Industrial and Corporate Change, 3(3), 537-556. https://doi.org/10.1093/icc/3.3.537-a

Tilman, D., \& Downing, J. A. (1994). Biodiversity and stability in grasslands. Nature, 367(6461), 363-365. https://doi.org/10.1038/367363a0

Walker, Brian \& Hollin, CS \& Carpenter, Stephen \& Kinzig, A. (2004). Resilience, Adaptability and Transformability in Social-Ecological Systems. Ecology and Society, 9 (2): 5 Retrieved from https:// www.ecologyandsociety.org/vol9/iss2/art5/print.pdf

Walker, B., et al. (2002). Resilience management in social-ecological systems: A working hypothesis for a participatory approach. Ecology and Society, 16(1). Retrieved from https://www.ecologyandsociety. org/vol6/iss1/art14/print.pdf

Wang, C. L., \& Ahmed, P. K. (2007). Dynamic capabilities: A review and research agenda. International Journal of Management Reviews, 9(1), 31-51. https://doi.org/10.1111/j.1468-2370.2007.00201.x

Wernerfelt, B. (1984). A resource-based view of the firm. Strategic Management Journal, 5(2), 171-180. https://doi.org/10.1002/smj.4250050207

Wernerfelt, B. (1995). The resource-based view of the firm: Ten years after. Strategic Management Journal, 16(3), 171-174. https://doi.org/10.1002/smj.4250160303

Whitehorn, G. (2011). Risk Management: Building Business Resilience. Keeping Good Companies, 63(7), 402-405. Recuperado https://search.informit.com.au/ documentSummary;dn=333581379859441;res=IELBUS

Winter, S. G. (2003). Understanding dynamic capabilities. Strategic Management Journal, 24(10), 991-995. https://doi.org/10.1002/smj.318

Yin, R. K. (2014). Case study research: design and methods. Los Angeles (CA), US: Sage Publications. 